\title{
New evidence of the sabertooth cat Smilodon (Carnivora: Machairodontinae) in the late Pleistocene of southern Chilean Patagonia
}

\author{
Nueva evidencia del gato dientes de sable Smilodon (Carnivora: Machairodontinae) en el \\ Pleistoceno tardío de Patagonia meridional chilena \\ ALFREDO PRIETO ${ }^{1}$, RAFAEL LABARCA ${ }^{2, ~ *} \&$ VÍCTOR SIERPE $^{1}$ \\ ${ }^{1}$ Instituto de la Patagonia, Universidad de Magallanes, Casilla 113-D, Punta Arenas, Chile \\ ${ }^{2}$ Programa de Doctorado Universidad Nacional del Centro de la Provincia de Buenos Aires, Av. Del Valle 5737, Olavarría, \\ Argentina \\ * Corresponding author: r.labarca.e@gmail.com
}

\begin{abstract}
Southern Patagonia is rich in late Pleistocene mammals, especially herbivores such as Camelids, Equids and Xenarthrans. Carnivores, on the other hand, are not commonly found in the paleontological record. One genus, Smilodon, is of particular interest because its presence in the region has not been demonstrated. In this paper, we present new fossil dental evidence that supports the presence of Smilodon populator (Lund) in the region. This evidence corresponds to the most southern record of the genus in the world, and the final step in the colonization of South America after the Great American Biotic Interchange. An AMS radiocarbon date on teeth indicates that the remains from Southern Chilean Patagonia are the most recent record for the genus in South America.
\end{abstract}

Key words: late Pleistocene, Smilodon, southern Patagonia, taxonomy.

\section{RESUMEN}

Surpatagonia es particularmente rica en mamíferos finiplesitocenos, particularmente camélidos, équidos y xenartros. Los carnívoros, por su parte, se encuentran representados en menor número en el registro paleontológico. Dentro de estos, el género Smilodon, es de particular interés debido a que su presencia en la región no ha sido convincentemente demostrada. En este trabajo presentamos evidencia dental que permite confirmar la presencia de Smilodon populator (Lund) en la región. Esta evidencia corresponde al registro más sureño de este taxón y al paso final en la colonización de América del Sur después del Gran Intercambio Biótico Americano. Un fechado radiocarbónico directo AMS indica que los restos de Patagonia del Sur corresponden a los registros más tardíos para este género en el subcontinente.

Palabras clave: Patagonia del sur, Pleistoceno final, Smilodon, taxonomía.

\section{INTRODUCTION}

The genus Smilodon (Felidae, Machairodontinae) is one of the most conspicuous representatives of the popularly known 'sabertooth cats'. It is an exclusively American group, whose first records come from the north-east area of the continent about 2.5 million years ago (Berta 1985, 1987, Turner \& Antón 1997). Three species are distinguished from biometric and morphological attributes: S. gracilis (Cope, 1880), S. fatalis (Leidy, 1868) and S. populator (Lund, 1842) (Kurtén \& Werdelin 1990).

The oldest sabertooth cat from South America comes from the Argentinian Ensenadian Land Mammal Age (Plio-
Pleistocene), around 2.0 million years ago, through the species S. populator (Berta 1985, Soibelzon \& Prevosti 2007). Later, the nearctic taxon $S$. fatalis entered South America during the late Pleistocene (Kurtén \& Werdelin 1990). The sabertooth cat findings in the subcontinent suggest that its distribution was allopatric, since $S$. populator inhabited the east slope of the Andes, according to fossil remains found in Venezuela, Brazil, Paraguay, Uruguay, Argentina, Bolivia and Chile. S. fatalis occupied the west side of the Andes, including Ecuador and Perú (Berta 1985, Kurtén \& Werdelin 1990, Ubilla et al. 2004, Rincón 2006, Soibelzon \& Prevosti 2007). Both species disappear at the Pleistocene-Holocene boundary (Lujanian-Platean). 
For 60 years, all late Pleistocene felid remains from southern Chile have been systematically assigned to an extinct subspecies of jaguar, known as Panthera onca mesembrina (Cabrera 1934) (Nami \& Menegaz 1991, Latorre 1998, Massone 2004) until Canto in 1991, described a premaxillary from the paleontological site Cueva Lago Sofía 4, that corresponds to a Smilodon sp. (Canto 1991). From that moment on, earlier findings carried out in the area (e.g., Cueva del Milodón) and elsewhere were tentatively assigned to Smilodon or Smilodon populator (Mol et al. 2003, Barnett et al. 2005, Soibelzon \& Prevosti 2007) without making any taxonomic comparisons.

This work discusses the presence of Smilodon, and particularly, S. populator during the late Pleistocene in the Chilean Patagonia, starting from fossils found in two well-known caves from the area, Cueva Lago Sofía 4 and Cueva del Medio.

\section{Study sites}

The specimens under study comes from the paleontological site of Cueva Lago Sofía 4 (CLS4) and the archaeological/paleontological site of Cueva del Medio (CDM), both located to the northeast of Última Esperanza Province, Magellan Region in southern chilean Patagonia
(Fig. 1). CLS-4 is a small cave (16 m long) situated in the foothills of Cerro Mocho, about $150 \mathrm{~m}$ above sea level. The cave floor consists mainly of a compact carbonated matrix, but in some areas there are layers of silty sand sediments as well. The Smilodon remains were recovered from the back of the cave after systematic excavations, around 70 and $30 \mathrm{~cm}$ deep. Vicugna vicugna (Molina, 1782) and Mylodon darwini (Owen, 1839) bones have been dated $\left({ }^{14} \mathrm{C}\right)$ from $13,545 \pm 100 \mathrm{BP}$ (Ua-36261) $(13,732-14,625$ cal BP 2 sigmas) and $11,590 \pm$ 100 BP (PITT-0940) (13,255-13,676 cal BP 2 sigmas) (Borrero et al. 1997, Labarca \& Prieto 2009). CDM is located in the east flank of Cerro Benitez, about $5 \mathrm{~km}$ to the southwest of CLS-4 (Fig. 1). The cave is $87 \mathrm{~m}$ long and $41 \mathrm{~m}$ wide. Archaeological excavations documented a late Pleistocene human occupation associated with extinct fauna (Nami 1987). The Smilodon material was recovered in a grey-yellowish sandy matrix about $90 \mathrm{~cm}$ deep. Dates $\left({ }^{14} \mathrm{C}\right)$ taken from charcoal and bone ranged from 9,595 \pm 115 BP (PITT-0344) $(8,646-9,266$ cal BP 2 sigmas) to $12,390 \pm 180 \mathrm{BP}$ (PITT-0343) (11,968-13,095 cal BP 2 sigmas) (Nami 1987, Nami \& Nakamura 1995). Also, in this research a direct Smilodon AMS ${ }^{14} \mathrm{C}$ date was obtained from the CEHA 29/12bN408 specimen (Table 1).

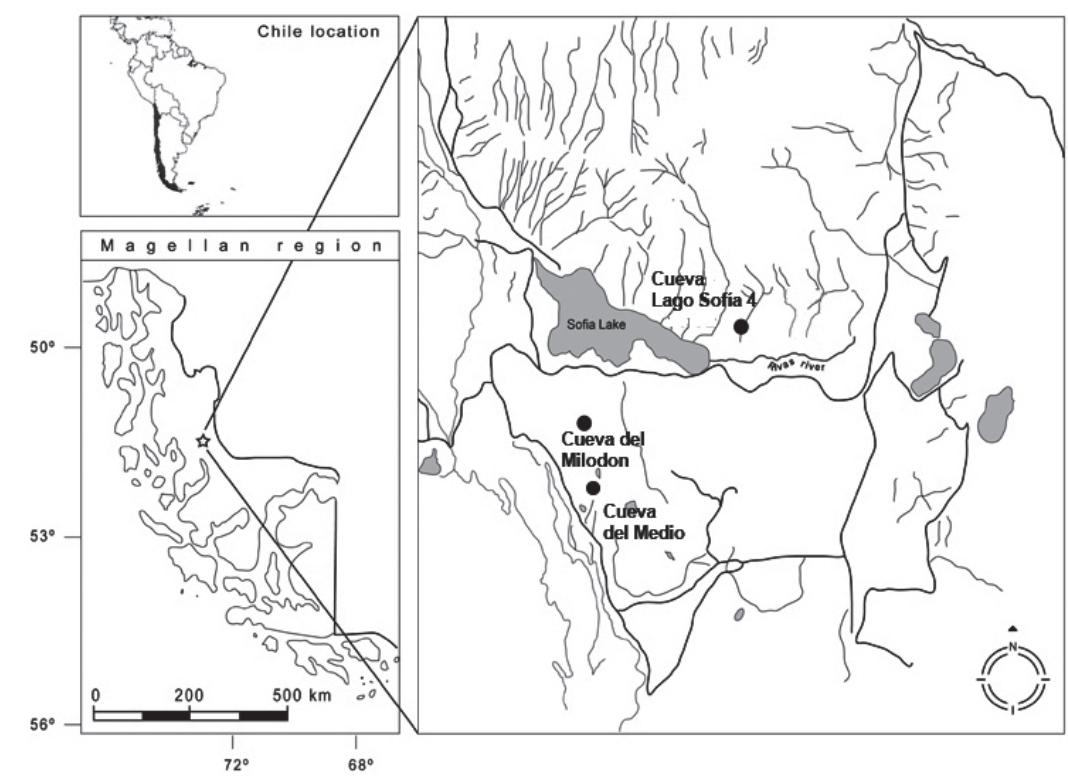

Fig. 1: Location of the archaeological and paleontological sites of Cueva Lago Sofía 4 and Cueva del Medio. Ubicación de los sitios arqueológicos y paleontológicos de Cueva Lagos Sofía 4 y Cueva del Medio. 


\section{TABLE 1}

Smilodon bone/tooth AMS radiocarbon dates from southern Chile. Radiocarbon dates were calibrated using Calib 5.1 software (Stuiver \& Reimer 1993).

Fechados radiocarbónicos por AMS en huesos/dientes de Smilodon del sur de Chile. Los fechados radiocarbónicos fueron calibrados usando el software Calib 5.1 (Stuiver \& Reimer 1993).

\begin{tabular}{lcccc}
\hline Site & Lab code & Radiocarbon date & Calibrated age (2 sigmas) & Reference \\
\hline Cueva del Medio & Ua-37622 & $11,100 \pm 80$ & $10,935-11,209$ cal BP & This work \\
Cueva del Milodón & IB-249 & $11,420 \pm 50$ & $11,437-11,240$ cal BP & R Barnett, personal communication, 2010 \\
Cueva del Milodón & IB-247 & $11,265 \pm 45$ & $11,300-11,131$ cal BP & R Barnett, personal communication, 2010
\end{tabular}

\section{METHODS}

For the morphological analysis, the remains were compared with (1) modern dental pieces of Puma concolor (Linnaeus, 1758) stored at Centro de Estudios del Hombre Austral, Universidad de Magallanes (CEHA), Punta Arenas, Chile; (2) fossil material from Smilodon populator stored at Museo Argentino de Ciencias Naturales "Bernardino Rivadavia”, Buenos Aires, Argentina (MACN) and Museo de La Plata (MLP), La Plata, Argentina; and (3) a resin replica of Smilodon fatalis from Rancho La Brea stored at CEHA. Osteological terminology from Merriam and Stock (1932) was used for the description. In order to compare the size of the Smilodon specimens from Southern Chile with those found in other parts of America, we conducted an analysis of logarithmic distances ${ }^{1}$, using metrical data from Merriam \& Stock (1932), Berta $(1985,1987)$, Kurtén \& Werdelin (1990), as well as personal data gathered at MLP and MACN, and unpublished data from F. Prevosti (personal communication, 2008) (Appendix A and B). Meausurements are in milimeters with $0.1 \mathrm{~mm}$ accuracy.

The specimens under study are housed at the Centro de Estudios del Hombre Austral, Universidad de Magallanes (CEHA) in Punta Arenas, Chile.

\section{RESULTS}

\section{Systematic palaeontology}

Order Carnivora (Bowdich, 1821)

Suborder Feliformia (Kretzoi, 1945)

Family Felidae (Gray, 1821)

Subfamily Machairodontinae (Gill, 1872)

Tribe Smilodontini (Kurtén, 1963)

Genus Smilodon (Lund, 1842)

Smilodon populator (Lund, 1842) (Fig. 2A)

MEADOW R (1987) Techinques for comparing bones measurement data from small samples. Northeastern faunal analysis conference Storrs, Conneticut, USA.

\section{Referred specimen}

CLS-4: UMAG 86661(i-08) fragment of a leftupper canine.

\section{Description and comparison}

The piece UMAG 86661(i-08) corresponds to a proximal portion of a large left-upper canine. According to Berta (1985, 1987), the upper canine from Smilodon genus has unusual growth, lateral compression, acuminate morphology, curved towards its distal end and fine serrations on the edges. The piece from Lago Sofía 4, although it was fractured, has dimensions matching Smilodon (Appendix A) with a laterally compressed cross-section and a slight curvature. The specimen is only a root, so there is no distal serration. Despite the fact that it is incomplete, it is possible to obtain the maximum mesiodistal length (L) and maximum buccolingual width (W) (Appendix A).

Berta (1985) as well as Kurtén and Werdelin (1990) state that $S$. populator, particularly the Lujanian form is the largest species within the genus. Berta (1985, 1987), nevertheless, mentions that a classification based exclusively on size is not reliable because of sexual dimorphism and/or typical variations of animals with wide geographical distribution (i.e., "Bergmann's rule"). Kurtén and Werdelin (1990), however, have demonstrated that although there was some degree of sexual dimorphism in Smilodon, this was less than in other widespread felids (e.g., Puma concolor). The analysis of logarithmic distances using the canine bucolingual maximum width and taking MLP-83-I-15-3 as reference (Appendix A) indicates that the CLS- 4 tooth has a size compatible only with $S$. populator (Fig. 3A). 

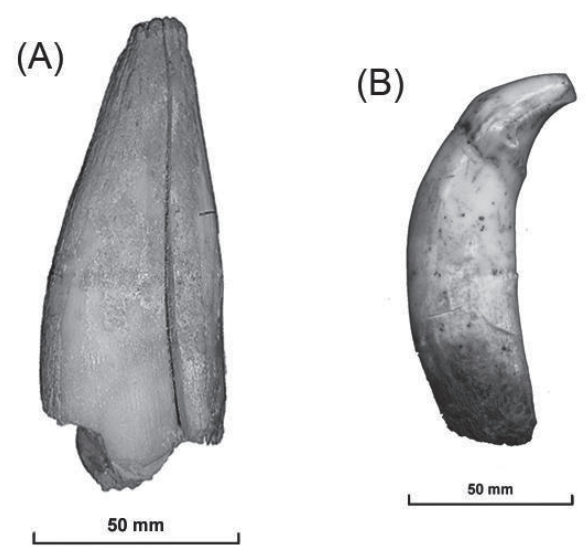

(C)

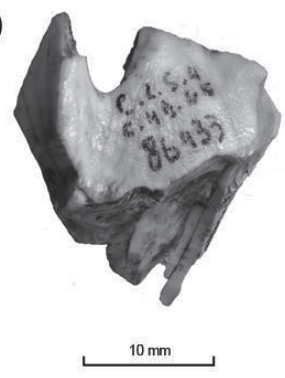

(D)

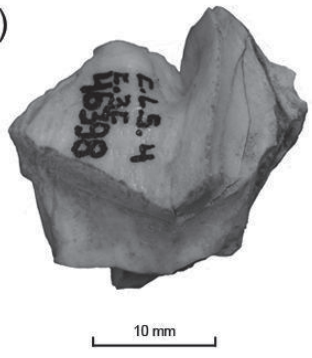

Fig. 2: Dental remains of Smilodon of CLS-4 and CDM. Smilodon populator: (A) Fragment of a left-upper canine (UMAG 86661[i-08]), buccal view; Smilodon cf. S. populator: (B) Right-upper third incisor (UMAG 29/ 12bN408), buccal view; (C) Fragment of a left-upper fourth premolar (UMAG 86433), lingual view; (D) Fragment of a right-upper fourth premolar (UMAG 46388), buccal view.

Restos dentales de Smilodon de CLS-4 y CDM. Smilodon populator: (A) Fragmento de canino superior izquierdo (UMAG 86661[i-08]), vista bucal; Smilodon cf. S. populator: (B) Tercer incisivo superior derecho (UMAG 29/12bN408), vista bucal; (C) Fragmento de cuarto premolar superior izquierdo (UMAG 86433), vista lingual; (D) Fragmento de cuarto premolar superior derecho (UMAG 46388), vista bucal.

\section{Smilodon cf. S. populator}

\section{Referred specimens}

CDM: UMAG 29/12bN408 right-upper third incisor (Fig. 2B); CLS-4: UMAG 86433 (Fig. 2C) fragment of a left-upper fourth premolar; UMAG 46388 (Fig. 2D) fragment of a rightupper fourth premolar.

\section{Description and comparison}

The piece UMAG 29/12bN408 is a large rightupper third incisor. It has a great development of the main cusp, an oval section, a slight compression in its lateral section, and is curved towards its distal end. Its medial side has a groove that runs from the tip of the crown to its base. The enamel on its lateral side is fractured. Both sides of the lingual section show two slightly flattened posterior tubercles separated by a "U" shaped notch. It is worn on its occlusal surface. The big size of this tooth (Appendix B), the presence of a prominent root and posterior tubercles are features of Smilodon (Merriam \& Stock 1932). The logarithmic distances using the third incisor bucolingual maximum width (W) taking the MLP 10-2 specimen as reference (Appendix B) shows that the UMAG 29/
$12 \mathrm{bN} 408$ tooth has dimensions similar to the largest specimens of $S$. fatalis from the Rancholabrean of North America and $S$. populator of Lujanian of South America (Fig. 3B, Appendix B), suggesting that this tooth does not have a specific taxonomic value. However, it is assigned to Smilodon cf $S$. populator due to its morphological and size features, chronological contemporaneity, geographical proximity and faunal composition between CDM and CLS-4. The fact that $S$. fatalis and $S$. populator have an allopatric distribution in South America supports this assignation (Kurtén \& Werdelin 1990).

UMAG 86433 and UMAG 46388 correspond to left and right fourth premolar fragments, respectively. Both are fractured in a very similar way, retaining the upper portion of the crown. The specimen UMAG 86433 has an almost complete metacone with a small lingual portion of the paracone. It also has a fragment of the principal root, and shows intensive occlusal wear exposing the dentine. The specimen UMAG 46388 also retains the distal section of the crown conserving a large mesial portion of the metacone and the distal portion of the paracone. The deep depression that divides both sections is complete. It has a very advanced occlusal wear on the lingual side. The similarities in occlusal wear and general 
size between both premolars, suggests that they probably came from the same individual. Due to the fragmentary nature of the specimens, it is impossible to obtain reliable measurements, however, the very prominent metacone and a marked depression between the metacone and the paracone are distinctive features of the genus Smilodon (Merriam \& Stock 1932). Due to extensive fragmentation, UMAG 46388 and UMAG 86433 cannot be specifically assigned, however their stratigraphic relationship with UMAG-86661(i08) permits their inclusion with the other Simlodon cf. S. populator material.

\section{DISCUSSION}

Remains of Smilodon populator have been documented in Venezuela, Brazil, Paraguay, Uruguay, Argentina, Bolivia and Chile (Berta \& Marshal 1978, Berta 1985, Kurtén \& Werdelin 1990, Ubilla et al. 2004, Rincón
2006). Not counting the Patagonian findings, the southernmost record of Smilodon comes from the late-Pleistocene (Lujanian-Platean) in Central Argentina (Soibelzon \& Prevosti 2007). The radiocarbon date of the Smilodon tooth from Cueva del Medio corresponds to the most recent record of this taxon in South America and the southernmost occurence. The date is slightly younger than those obtained from Cueva del Milodon (Table 1).

The paleoclimatological data of the area shows that when the now extinct megafauna was alive, the climate was very cold and the landscape vegetation was more open (Heusser 1995, Cárdenas 2006, Villa-Martínez \& Moreno 2007). This agrees with the faunal assemblages identified in CLS-4 and CDM, since Smilodon populator remains were found along with remains of the common grazers of open landscapes such as Mylodon darwini, Hippidion saldiasi (Roth, 1899), Lama guanicoe (Müller, 1776) and Vicugna vicugna (Nami \& Mengaz 1991, Borrero et al. 1997).

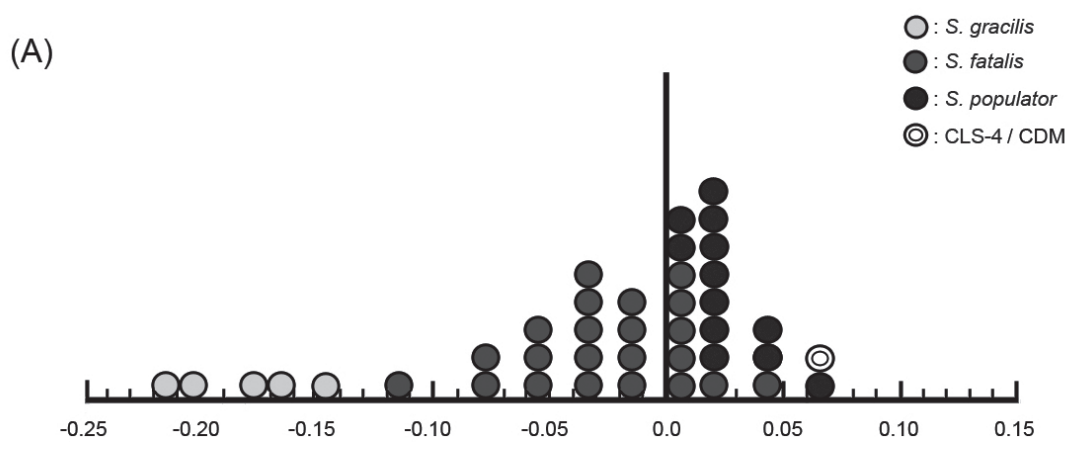

(B)

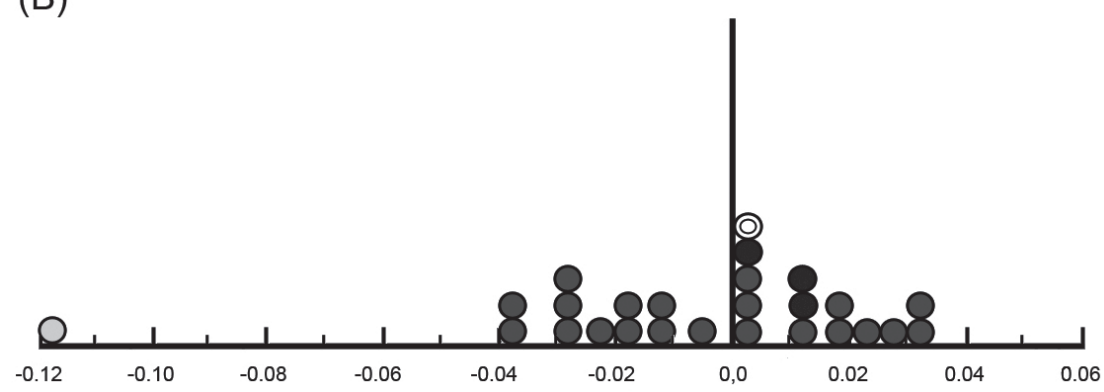

Fig. 3: Logarithmic distances of dental pieces of Smilodon genus. (A) $\mathrm{C}^{1}$, taking as a reference the piece MLP-83-I-15-3 (Appendix A); (B) I³, taking as a reference the piece MLP 10-2 (Appendix B). 
During the late Pleistocene, Smilodon populator was at the top of the foodweb. Prevosti \& Vizcaíno (2006) suggest that S. populator could have captured an animal of $1,871 \mathrm{~kg}$. For this reason, all the Pleistocene mammals recorded in southern Patagonia were potentially prey. In this scenario, $S$. populator competed against other large carnivores, such as Arctotherium tarijense (Ameghino 1902) and Panthera onca mesembrina. The morphology of the limbs suggests that Smilodon was not able to run long distances and accelerate quickly, thus, its hunting strategy most likely focused on ambush instead of pursuit in relatively closed environments (Gonyea 1976, Turner \& Antón 1997). Given the large areas of open landscape in southern Patagonia, S. populator may have complemented its hunting strategy by incorporating pursuit at least occasionally. The presence of this sabertooth at the very tip of South America demonstrates the high adaptability of the species.

\section{ACKNOWLEDGMENTS}

We thank A. Kusanovic and his wife (Lago Sofía sheepfarm); P. Cárdenas, E. Calás, S. Morano, G. Bahamóndes, T. Dupradou and F. Busolich for capable field assistance; L. Pomi and M. Regueiro (MLP) for assisting RLE during the visit to the MLP; A. Kramarz (MACN) for assisting RLE during the visit to the MACN; F. Prevosti (MACN) helped with measurements of incisor specimens. H.G. Nami for CDM information. R. Barnett provided the radiocarbon dates from Cueva del Milodón. C. Hernández, K. Miller and R. Cárdenas collaborated with the translation. This research was funded by Fondecyt grant \# 1070709.

\section{LITERATURE CITED}

AMEGHINO F (1902) Notas sobre algunos mamíferos fósiles nuevos o poco conocidos del valle de Tarija. Anales del Museo Nacional de Buenos Aires (Argentina) 3: 225-261.

BARNETT R, I BARNES, MJ PHILLIPS, LD MARTIN, CR HARINGHTON, JA LEONARD \& AL COOPER (2005) Evolution of the extinct sabretooth and the America cheetah-like cat. Current Biology 15: R589-R590.

BERTA A (1985) The status of Smilodon in North and South America. Contributions in Science, Natural History Museum of Los Angeles County 370: $1-15$

BERTA A (1987) The sabercat Smilodon gracilis and discussion of its relationship (Mammalia, Felidae, Smilodontini). Bulletin of the Florida State Museum Biological Science 31: 1-63.
BERTA A \& LG MARSHAL (1978) South American Carnivora. In: Junk W (ed) Fossilium catalogus: 1-48. The Hague Boston \& London, UK.

BORRERO LA, FM MARTIN \& A PRIETO (1997) La Cueva Lago Sofía 4, Ultima Esperanza: Una madriguera de felino del Pleistoceno tardío. Anales del Instituto de la Patagonia Serie Ciencias Humanas (Chile) 25: 103-122.

BOWDICH TE (1821) An analysis of the natural classifications of Mammalia for the use of students and travelers. J. Smith, Paris, France.

CABRERA A (1934) Los yaguares vivientes y extinguidos de la América austral. Notas Preliminares del Museo de la Plata (Argentina) 2: $34-50$.

CANTO J (1991) Posible presencia de una variedad de Smilodon en el Pleistoceno tardío de Magallanes. Anales del Instituto de la Patagonia Serie Ciencias Sociales (Chile) 20: 96-99.

CÁRDENAS M (2006) Vegetación y clima postglacial en Última Esperanza, Patagonia sur de Chile. M.S. Thesis, Universidad de Chile, Facultad de Ciencias, Santiago, Chile.

COPE ED (1880) On the extinct cats of America. American Naturalist 14: 833-858.

GILL T (1872) Arrangement of the families of mammals with analytical tables. Smithsonian Miscelanea Collection 1: 1-98.

GONYEA WJ (1976) Behavioral implications of sabertoothed felid morphology. Palaeobiology 2: 332342.

GRAY JE (1821) On the natural arrangement of vertebrose animals. London Medical Repository 5: 296-310.

HEUSSER CJ (1995) Three late Quaternary pollen diagrams from southern Patagonia and their palaeoecological implications. Palaeogeography, Palaeoclimatology, Palaeoecology 118: 1-24.

KRETZOI M (1945) Bemerkungen über das Raubtiersystem. Annales Historico-Naturales Museum Nationale Hungaricum 38: 59-83.

KURTÉN B (1963) Notes on some Pleistocene mammal migrations from the Palaearctic to the Nearctic. Eiszeitalter und Gegenwart 14: 96-103.

KURTÉN B \& L WERDELIN (1990) Relationships between North and South American Smilodon. Journal of Vertebrate Paleontology 10: 158-169.

LABARCA R \& A PRIETO (2009) Osteometría de Vicugna vicugna Molina, 1782 en el Pleistoceno final de Patagonia meridional chilena: Implicancias paleoecológicas y biogeográficas. Revista del Museo de Antropología (Argentina) 2: $127-140$.

LATORRE C (1998) Paleontología de mamíferos del altero Tres Arroyos I, Tierra del Fuego, XII Región, Chile. Anales del Instituto de la Patagonia Serie Ciencias Naturales (Chile) 26: 77-90.

LEIDY J (1868) Notice of some vertebrate remains from Hardin County, Texas. Proceedings of the Academy of Natural Science of Philadelphia 20: 174-176.

LINNAEUS C (1758) Systema naturae per regna tria naturae secundum classes, ordines, genera, species, cum characteribus, differentiis, synonymis, locis. Salvii, Stockholm.

LUND PW (1842) Blik paa Brasiliens dyreverden für sidste Jordomvaeltning. Fjerde Afhandling: Fortsaettelse af Pattedryene 9: 137-208.

MASSONE M (2004) Los cazadores después del Hielo. 
Ediciones de la Dirección de Archivos y Museos, Santiago, Chile.

MERRIAM JC \& C STOCK (1932) The Felidae of Rancho La Brea. Carnegie Institution of Washington Publication 422: 1-231.

MOL D, PJH VAN BREE \& GH MCDONALD (2003) De Amsterdamse collectie fossielen uit de grot van Ultima Esperanza (Patagonië, Zuid-Chili). Grondboor en Hamer 2: 26-31.

MOLINA GI (1782) Saggio sulla storia naturale del Chile. Fratelli Masi e Co, Bologna, Italy.

MÜLLER PLS (1776) Erste classe, säugende thiere. In: Des Ritters Carl von Linné vollständiges naturalsystem nach der zwölften Lateinischen ausgabe,1773-1776: 1-62 + 3 pl.

NAMI HG (1987) Cueva del Medio: Perspectivas arqueológicas para la Patagonia Austral. Anales del Instituto de la Patagonia Serie Ciencias Humanas (Chile) 17: 73-106.

NAMI HG \& A MENEGAZ (1991) Cueva del Medio: Aportes para el conocimiento de la diversidad faunística hacia el Pleistoceno-Holoceno en la Patagonia Austral. Anales del Instituto de la Patagonia Serie Ciencias Humanas (Chile) 20: 117-132.

NAMI HG \& T NAKAMURA (1995) Cronología radiocarbónica con AMS sobre muestras de huesos procedentes del sitio Cueva del Medio (Última Esperanza, Chile). Anales del Instituto de la Patagonia Serie Ciencias Humanas (Chile) 23: 125-133.

OWEN R (1839) Fossil mammalia. In: Darwin C (ed) The zoology of the voyage of H.M.S. Beagle under the command of captain Fitzroy R.N., during the Years 1832 to 1836 : 13-111+ XXXII P1. Smith, Elder \& Co, London, UK.

Associate Editor: Claudio Latorre

Received October 28, 2009; accepted March 29, 2010
PREVOSTI F \& SF VIZCAÍNO (2006) Paleoecology of the large carnivore guild from the late Pleistocene of Argentina. Acta Palaeontologica Polonica 51: 407-422.

RINCÓN A (2006) A first record of the Pleistocene saber-toothed cat Smilodon populator Lund, 1842 (Carnivora: Felidae: Machairodontinae) from Venezuela. Ameghiniana 43: 499-501.

ROTH S (1899) El mamífero misterioso de la Patagonia Grypotherium domesticum. II. Descripción de los restos encontrados en la caverna de Última Esperanza. Revista del Museo de La Plata 9: 421453.

SOIBELZON LH \& F PREVOSTI (2007) Los carnívoros (Carnivora, Mammalia) terrestres del Cuaternario de América del Sur. In: Pons GX \& D Vicens (eds) Geomorfología litoral i Quaternari. Homenatge a Joan Cuerda Barceló: 49-68. Monografies de la Societat d'Història Natural de les Balears, Palma de Mallorca.

STUIVER M \& PJ REIMER (1993) Extended 14C data base and revised calib 3.01 14C calibration program. Radiocarbon 35: 215-230.

TURNER A \& M ANTÓN (1997) The big cats and their fossil relatives. Columbia University Press, New York, USA.

UBILLA M, D PEREA, C GOSO AGUILAR \& N LORENZO (2004) Late Pleistocene vertebrates from northern Uruguay: Tools for biostratigraphic, climatic and environmental reconstruction. Quaternary International 114: 129-142.

VILLA-MARTÍNEZ R \& P MORENO (2007) Pollen evidence for variations in the southern margin of the westerly winds in SW Patagonia over the last 12,600 years. Quaternary Research 68: 400-409. 


\section{APPENDIX A}

Upper-left canine measures (mm) of Smilodon genus.

Medidas ( $\mathrm{mm}$ ) de caninos superiores izquierdos del género Smilodon.

\begin{tabular}{|c|c|c|c|c|}
\hline Repository code & Taxa & $\mathrm{L}$ & $\mathrm{W}$ & Reference \\
\hline CEHA-86661(i-08) & S. populator & 43.6 & 25.1 & This work \\
\hline MLP 10-2 & S. populator & 43.5 & 21.3 & This work \\
\hline MLP 10-2 & S. populator & 43.1 & 21.6 & This work \\
\hline MLP 98-II-20-1 & S. populator & 45.4 & 23.3 & This work \\
\hline MLP 83-I-15-1 & S. populator & 42.1 & 21.5 & This work \\
\hline MLP 83-1-15-3 & S. populator & - & 22.2 & This work \\
\hline MLP 55-VIII-12-1 & S. populator & 44.5 & 20.7 & This work \\
\hline CM La Plata & S. populator & 44.5 & 20.7 & Kurtén \& Werderlin 1990 \\
\hline $\mathrm{CM}$ Arroyo Pergamino & S. populator & 44.3 & 22.1 & Kurtén \& Werderlin 1990 \\
\hline CM La Plata & S. populator & 45.9 & 21.8 & Kurtén \& Werderlin 1990 \\
\hline CM Lapa Escrivania & S. populator & 49.2 & 25 & Kurtén \& Werderlin 1990 \\
\hline CM Lapa Escrivania & S. populator & 44.3 & 22.3 & Kurtén \& Werderlin 1990 \\
\hline CM Lapa Escrivania & S. populator & 44.7 & 22.8 & Kurtén \& Werderlin 1990 \\
\hline ROM 2121 & S. fatalis & 43.3 & 15.5 & Kurtén \& Werderlin 1990 \\
\hline $2001-24$ & S. fatalis & 46.1 & 22.9 & Merriam \& Stock 1932 \\
\hline $2001-230$ & S. fatalis & 44 & 21.7 & Merriam \& Stock 1932 \\
\hline $2001-225$ & S. fatalis & 43.7 & 24.1 & Merriam \& Stock 1932 \\
\hline $2001-151$ & S. fatalis & 41.7 & 22.2 & Merriam \& Stock 1932 \\
\hline $2001-77$ & S. fatalis & 41.4 & 18.8 & Merriam \& Stock 1932 \\
\hline $2001-111$ & S. fatalis & 41.9 & 22.3 & Merriam \& Stock 1932 \\
\hline $2001-132$ & S. fatalis & 44.1 & 22.6 & Merriam \& Stock 1932 \\
\hline $2001-288$ & S. fatalis & 45.6 & 21.4 & Merriam \& Stock 1932 \\
\hline $2001-16$ & S. fatalis & 41.5 & 21.4 & Merriam \& Stock 1932 \\
\hline $2001-181$ & S. fatalis & 43 & 21.2 & Merriam \& Stock 1932 \\
\hline $2001-19$ & S. fatalis & 42.1 & 20.5 & Merriam \& Stock 1932 \\
\hline 2001-65 & S. fatalis & 46.1 & 20.4 & Merriam \& Stock 1932 \\
\hline $2001-2$ & S. fatalis & 45 & 23 & Merriam \& Stock 1932 \\
\hline $2001-5$ & S. fatalis & 43.5 & 21 & Merriam \& Stock 1932 \\
\hline $2001-307$ & S. fatalis & 38.1 & 21.7 & Merriam \& Stock 1932 \\
\hline $2001-311$ & S. fatalis & 40 & 20.1 & Merriam \& Stock 1932 \\
\hline $2001-302$ & S. fatalis & 42.2 & 19.8 & Merriam \& Stock 1932 \\
\hline $2001-90$ & S. fatalis & 41 & 19.3 & Merriam \& Stock 1932 \\
\hline $2001-131$ & S. fatalis & 43 & 19.7 & Merriam \& Stock 1932 \\
\hline $2001-4$ & S. fatalis & 42.2 & 19.7 & Merriam \& Stock 1932 \\
\hline $2001-256$ & S. fatalis & 36 & 18.8 & Merriam \& Stock 1932 \\
\hline $2001-113$ & S. fatalis & 38.6 & 16.6 & Merriam \& Stock 1932 \\
\hline $2001-76$ & S. fatalis & 39 & 18 & Merriam \& Stock 1932 \\
\hline $2001-148$ & S. fatalis & 38.8 & 18 & Merriam \& Stock 1932 \\
\hline ANSP 47 & S. gracilis & 26.8 & 13.3 & Berta 1987 \\
\hline ANSP 46 & S. gracilis & 25.9 & 13.1 & Berta 1987 \\
\hline ANSP 44 & S. gracilis & 35.5 & 15.2 & Berta 1987 \\
\hline F:AM 95525 & S. gracilis & 29.7 & 14.2 & Berta 1987 \\
\hline F:AM 95526 & S. gracilis & 31.4 & 14.4 & Berta 1987 \\
\hline
\end{tabular}




\section{APPENDIX B}

Right-upper third incisor measures (mm) of Smilodon genus.

Medidas (mm) de terceros incisivos derechos del género Smilodon.

\begin{tabular}{|c|c|c|c|}
\hline Repository code & Taxa & $\mathrm{W}$ & Reference \\
\hline UMAG 29/12bN408 & $\mathrm{CDM}$ & 12 & This work \\
\hline MLP 10-2 & S. populator & 12 & This work \\
\hline MLP 55-VIII-12-I & S. populator & 12.4 & This work \\
\hline MACN 18057 & S. populator & 12.3 & F. Prevosti pers comm. \\
\hline $2001-24$ & S. fatalis & 13 & Merriam \& Stock 1932 \\
\hline $2001-230$ & S. fatalis & 12.9 & Merriam \& Stock 1932 \\
\hline $2001-225$ & S. fatalis & 12.4 & Merriam \& Stock 1932 \\
\hline $2001-151$ & S. fatalis & 12.5 & Merriam \& Stock 1932 \\
\hline $2001-111$ & S. fatalis & 11.2 & Merriam \& Stock 1932 \\
\hline $2001-132$ & S. fatalis & 11.6 & Merriam \& Stock 1932 \\
\hline $2001-288$ & S. fatalis & 12.5 & Merriam \& Stock 1932 \\
\hline $2001-16$ & S. fatalis & 11.5 & Merriam \& Stock 1932 \\
\hline $2001-181$ & S. fatalis & 11 & Merriam \& Stock 1932 \\
\hline $2001-19$ & S. fatalis & 12.6 & Merriam \& Stock 1932 \\
\hline $2001-2$ & S. fatalis & 12 & Merriam \& Stock 1932 \\
\hline $2001-5$ & S. fatalis & 12.8 & Merriam \& Stock 1932 \\
\hline $2001-307$ & S. fatalis & 11.5 & Merriam \& Stock 1932 \\
\hline $2001-311$ & S. fatalis & 11.9 & Merriam \& Stock 1932 \\
\hline $2001-302$ & S. fatalis & 11.3 & Merriam \& Stock 1932 \\
\hline $2001-90$ & S. fatalis & 11.6 & Merriam \& Stock 1932 \\
\hline $2001-131$ & S. fatalis & 11.4 & Merriam \& Stock 1932 \\
\hline $2001-4$ & S. fatalis & 11.3 & Merriam \& Stock 1932 \\
\hline $2001-256$ & S. fatalis & 11.1 & Merriam \& Stock 1932 \\
\hline $2001-113$ & S. fatalis & 11.7 & Merriam \& Stock 1932 \\
\hline $2001-76$ & S. fatalis & 12 & Merriam \& Stock 1932 \\
\hline ANSP 44 & S. gracilis & 9 & Berta 1987 \\
\hline
\end{tabular}


